\title{
Game Edukasi Anak Usia Dini Berbasis Android Menggunakan Adobe Flash CS6
}

\author{
Ani Hartati, Fajriyah \& Khana Wijaya \\ Sekolah Tinggi Manajemen Informatika dan Komputer Pabumulih \\ Email : $\underline{\text { hartatiani22@yahoo.com }}$
}

\begin{abstract}
In this method the author uses the UCD (User Centered Design) system development method and analysis and system design tools using a Flowchart (Flowchart) programming language used JAVA language with Adobe Flash CS6 application. This application was created aiming to be able to help early childhood, kindergarten/PAUD level students as well as teachers and parents in introducing and teaching letters, numbers, fruit, colors, animals, shapes and vehicles.
\end{abstract}

Keywords : Game Edukasi, Android, UCD, Adobe Flash CS6

\section{Pendahuluan}

Seiring berjalannya waktu kemajuan teknologi berkembang sangat pesat dan memberikan dampak yang cukup besar dalam berbagai bidang salah satunya dalam bidang pendidikan. Pendidikan adalah sebuah proses pembelajaran yang didapat oleh setiap manusia, dalam hal ini adalah peserta didik, tujuannya adalah untuk membuat peserta didik itu paham, mengerti serta mampu berfikir lebih kritis. Pendidikan dapat dirumuskan sebagai tuntunan pertumbuhan manusia sejak lahir hingga tercapai kedewasaan jasmani dan rohani, dalam interaksi alam dan lingkungan masyarakat. Pendidikan merupakan proses yang terus menerus, tidak berhenti (Muhammad Iqbal Hanafri, dkk, 2015:50). Pendidikan merupakan hal yang terpenting dalam hidup kita, karena dengan pendidikan manusia dapat terbantu dalam bertahan hidup dan menyelesaikan suatu permasalahan. Serta menjadi seorang yang terdidik itu sangat penting. Pendidikan yang pertama kali kita dapatkan adalah dari lingkungan kelurga, lingkungan sekolah, dan lingkungan masyarakat. Usia dini merupakan usia emas bagi anak dalam menerima dan menangkap hal yang baru.

Game edukasi adalah salah satu jenis media yang digunakan untuk memberikan pengajaran, menambah pengetahuan penggunanya melalui suatu media unik dan menarik (Muhammad Iqbal Hanafri, dkk, 2015). Media interaktif yang menarik adalah menggunakan sistem pembelajaran melaui game berbasis android, di mana game sangat di sukai oleh anak-anak usia dini. Game yang akan di buat adalah game edukasi berbasis android yang memperkenalkan Huruf Alfabet, mengenal angka, mengenal buah, mengenal warna, mengenal hewan, mengenal bentuk dan mengenal kendaraan. Di dalam game ini pemain dapat langsung memilih menu game alfabet, angka, buah, warna, hewan, bentuk dan kendaraan, setelah di pilih, game akan menampilkan sebuah huruf atau gambar yang di sertai pertanyaan melaui audio dan si-pemain harus menjawab dengan memilih huruf atau gambar yang di tampilkan pada game.

Berdasarkan latar belakang di atas, maka penulis melakukan penelitian yang berjudul "GAME EDUKASI ANAK USIA DINI BERBASIS ANDROID MENGGUNAKAN ADOBE FLASH CS6" 


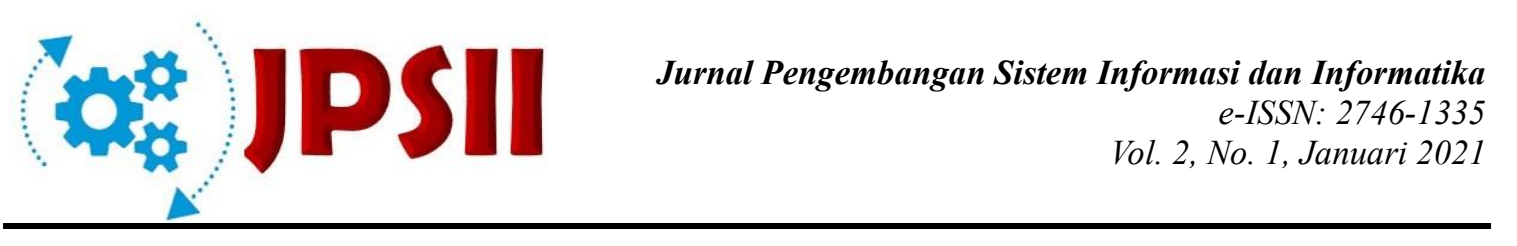

\section{Tinjauan Literatur}

\subsection{Game}

Menurut Putri Ludvyah Ekawati (2015:5-31), Game merupakan sarana yang menangani hubungan input/output, yang di kemas dalam sebuah sistem dimana pemain terlibat dalam konflik buatan yang sudah ditentukan oleh aturan untuk menghasilkan suatu tujuan tertentu. game adalah media hiburan dalam bentuk pertandingan dan di akhir pertandingan biasanya ada pihak yang kalah dan menang.

\subsection{Game Edukasi}

Menurut Muhammad Iqbal Hanafri dkk (2015:50), Game edukasi adalah salah satu jenis media yang digunakan untuk memberikan pengajaran, menambah pengetahuan penggunanya melalui suatu media unik dan menarik. Jenis permainan ini biasanya ditujukan untuk anak-anak, maka permainan warna sangat diperlukan disini, bukan tingkat kesulitan permainannya yang dipentingkan. Game edukasi adalah game yang di rancang untuk memberikan pengalaman pendidikan atau pengalaman belajar kepada user. Game edukasi dapat merangsang imajinasi pada anak.

\subsection{Pengertian Anak Usia Dini}

Menurut Yuliani Nurani Sujiono (2013), Anak usia dini adalah sosok individu yang sedang menjalani suatu proses perkembangan dengan pesat dan fundamental bagi kehidupan selanjutnya. Pada usia ini anak memiliki rasa penasaran atau ingin tahu yang sangat besa, maka dari itu kita sebagai guru atau orang tua memberikan pengetahuan yang baik untuk si-anak.

\subsection{Android}

Menurut Eliza (2012), Android merupakan sistem operasi yang perkembangannya sangat masif dan cepat. Saat ini, android sudah identik dengan smartphone. Android adalah sistem operasi mobile yang open source. Android juga identik dengan telepon selular dengan layar sentuh.

\subsubsection{Fitur Aplikasi Android}

a. Framwork aplikasi : memungkinkan penggunaan dan pemindahan dari komponen yang tersedia.

b. Dalvik virtual machine : virtual machine yang dioptimalkan untuk perangkat mobile.

c. Grafik : grafik 2D dan grafik 3D yang didasarkan pada library Open GL.

d. SQLite : untuk penyimpanan data.

e. Mendukung media : audio, video, dan berbagai format gambar (MPEG4, H.246, AAC, AMR, JPG, PNG, GIF).

f. GSM, Bluetooth, EDGE, 3G, and WIFI (tergantung hardware)

g. Camera, Global Positioning System (GPS), compass dan accelerometer (tergantung hardware)

h. Lingkungan pengembangan yang kaya, termasuk emulator, peralatan debugging, dan plugin untuk Eclipse IDE.

\subsubsection{Struktur Aplikasi Android}

Empat komponen pada aplikasi Android, yaitu :

a. Activities merupakan komponen untuk menyajikan tampilan pemakai (intervace user) kepada pengguna. 
b. Service merupakan komponen yang tidak memiliki tampilan pemakai (user interface),tetapi service berjalan secara backgrounds.

c. Broadcast Recaiver merupakan komponen yang berfungsi menerima dan breaksi untuk menyampaikan notifikasi.

d. Content Provider merupakan komponen yang membuat kumpulan aplikasi data secara spesifik, sehingga bias digunakan aplikasi lain

\subsection{Adobe Flash}

Menurut Akip Suhendra, Zaenal Mustofa (2014:2) Adobe Flash CS6 merupakan sebuah software yang didesain khusus oleh Adobe dan program aplikasi standar authoring tool profesional yang digunakan untuk membuat animasi dan bitmap yang sangat menarik untuk keperluan pembangunan situs web yang interaktif dan dinamis. Adobe Flash adalah bahasa pemrograman yang yang di gunakan oleh programer untuk membuat gambar, animasi dan game.

\subsection{Flowchart}

Menurut Ahmad Faris dan Pahlevy (2016:65), Flowchart (bagan alir) merupakan sebuah gambaran dalam bentuk diagram alir dari algoritma-algoritma dalam suatu program, yang menyatakan arah alur program tersebut. Flowchart adalah alat bantu dalam pengembangan sistem yang bertujuan untuk mempermudah seseorang dalam menunjukkan alir suatu program secara logika.

\section{Metode Penelitian}

\subsection{Objek Penelitian}

Objek penelitian pada TK Angelly Kids Prabumulih yang beralamt di Jl. Bukit Barisan Kelurahan Muara Dua Kecamatan Prabumulih Timur Kota Prabumulih Timur Sumatera Selatan.

\subsubsection{Struktur Organisasi TK Angelly Kids Kota Prabumulih}


STRUKTUR ORGANISASI PG.TK ANGELLY KIDS PRABUMULIH

TAHUN AJARAN 2018/2019

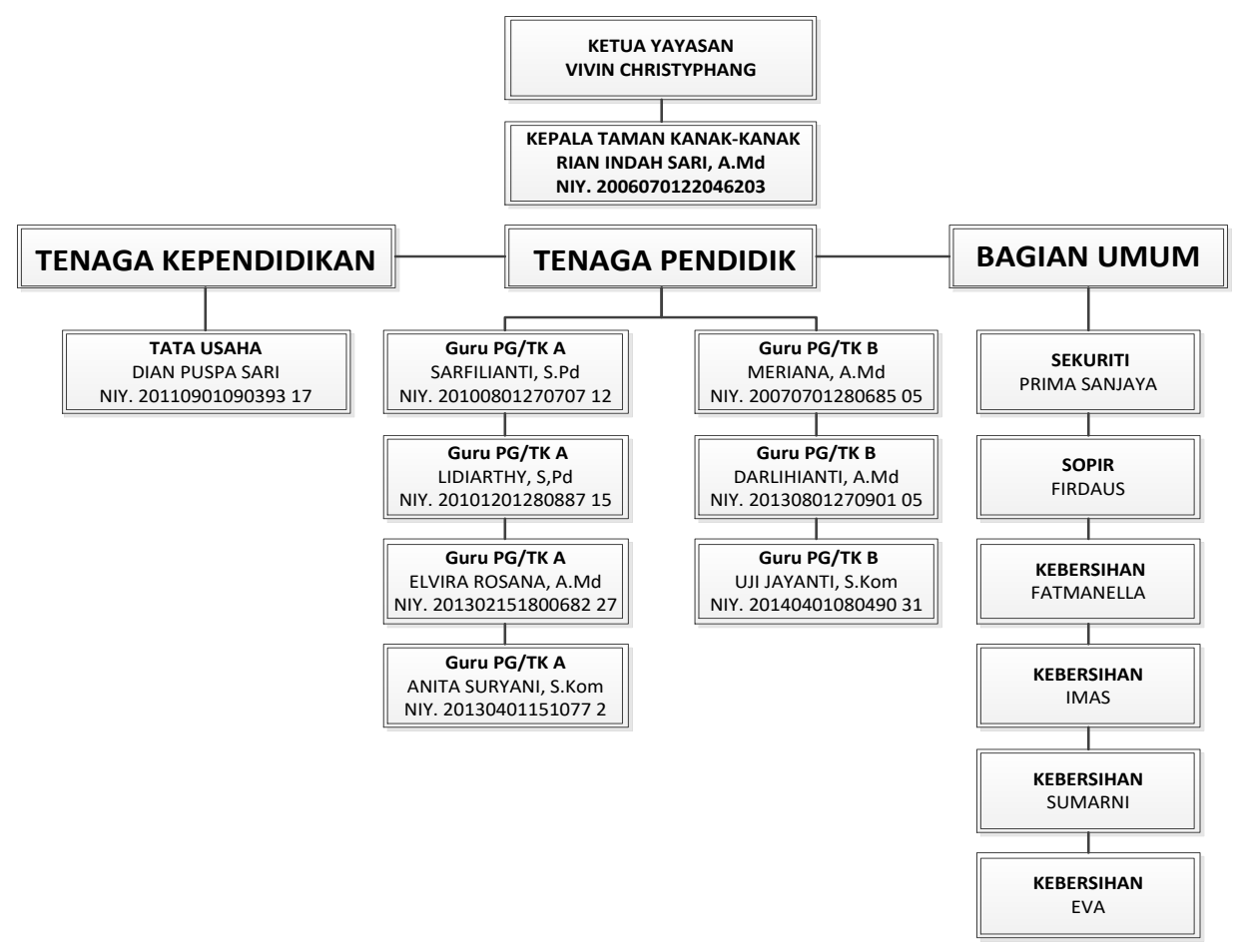

Gambar 3.1 Struktur Organisasi

Sumber : TK Angelly Kids Kota Prabumulih Tahun 2018

\subsection{Metode Penelitian}

Menurut Sugiyono (2015:2), Metode Penelitian pada dasarnya merupakan cara ilmiah untuk mendapatkan data dengan tujuan dan kegunaan tertentu. Berdasarkan hal tersebut empat kata kunci yang perlu diperhatikan yaitu, cara ilmiah, data, tujuan dan kegunaan. Cara ilmiah berarti kegiatan penelitian itu di dasarkan pada ciri-ciri keilmuan, yaitu rasional, empiris, dan sistematis. Metode yang digunakan metode penelitian deskriptif dengan pendekatan kualitatif.

\subsubsection{Desain Penelitian}

Desain penelitian mencakup proses-proses berikut:

a. Identifikasi dan pemilihan masalah penelitian.

b. Pemilihan kerangka konseptual untuk masalah penelitian serta hubungan-hubungan dengan peneliti sebelumnya.

c. Memformulasikan masalah penelitian termasuk membuat spesifikasi dan tujuan, luask jangkau (scope), dan hipotesis untuk diuji.

d. Membangun penyelidikan atau percobaan.

e. Memilih serta memberi definisi terhadap pengukuran variabel-variabel.

f. Memilih prosedur dan teknik sampling yang digunakan.

g. Menyusun alat serta teknik untuk mengumpulkan data.

h. Membuat coding, serta mengadakan editing dan procesing data.

i. Menganalisis data serta pemilihan prosedur statistik untuk mengadakan generalisasi serta inferensi statistik. 
j. Pelaporan hasil penelitian termasuk proses penelitian, diskusi serta interpretasi data, generalisasi, kekurangan-kekurangan dalam penemuan, serta menganjurkan beberapa saran-saran dan kerja penelitian yang akan datang.

\subsubsection{Metode Pengembangan Sistem}

A.

$$
\text { UCD (User Centered Design) }
$$

Menurut Intan Sandra Yatana Saputri (2017) UCD (User Centered Design) merupakan paradigma baru dalam pengembangan sistem berbasis web. User Centered design (UCD) juga sering disebut sebagai Human Centeres Design, menurut ISO 13407 (1999), human centered design adalah sebuah pendekatan pengembangan sistem interaktif yang secara khusus fokus untuk membuat sebuah sistem berguna. Definisi lainnya menurut [7], User Centered design adalah sebuah proses desain interface (antarmuka) yang fokus terhadap tujuan kegunaan, karakteristik pengguna, lingkungan, tugas, dan alur kerja di dalam desainnya. UCD adalah sebuah proses interative (berulang-ulang), dimana desain dan evaluasi di bangun dari langkah awal hingga implementasi secara terus menerus. Dalam proses User Centered design ini, ada 4 langkah yang dilakukan secara iterasi seperti gambar dibawah ini.

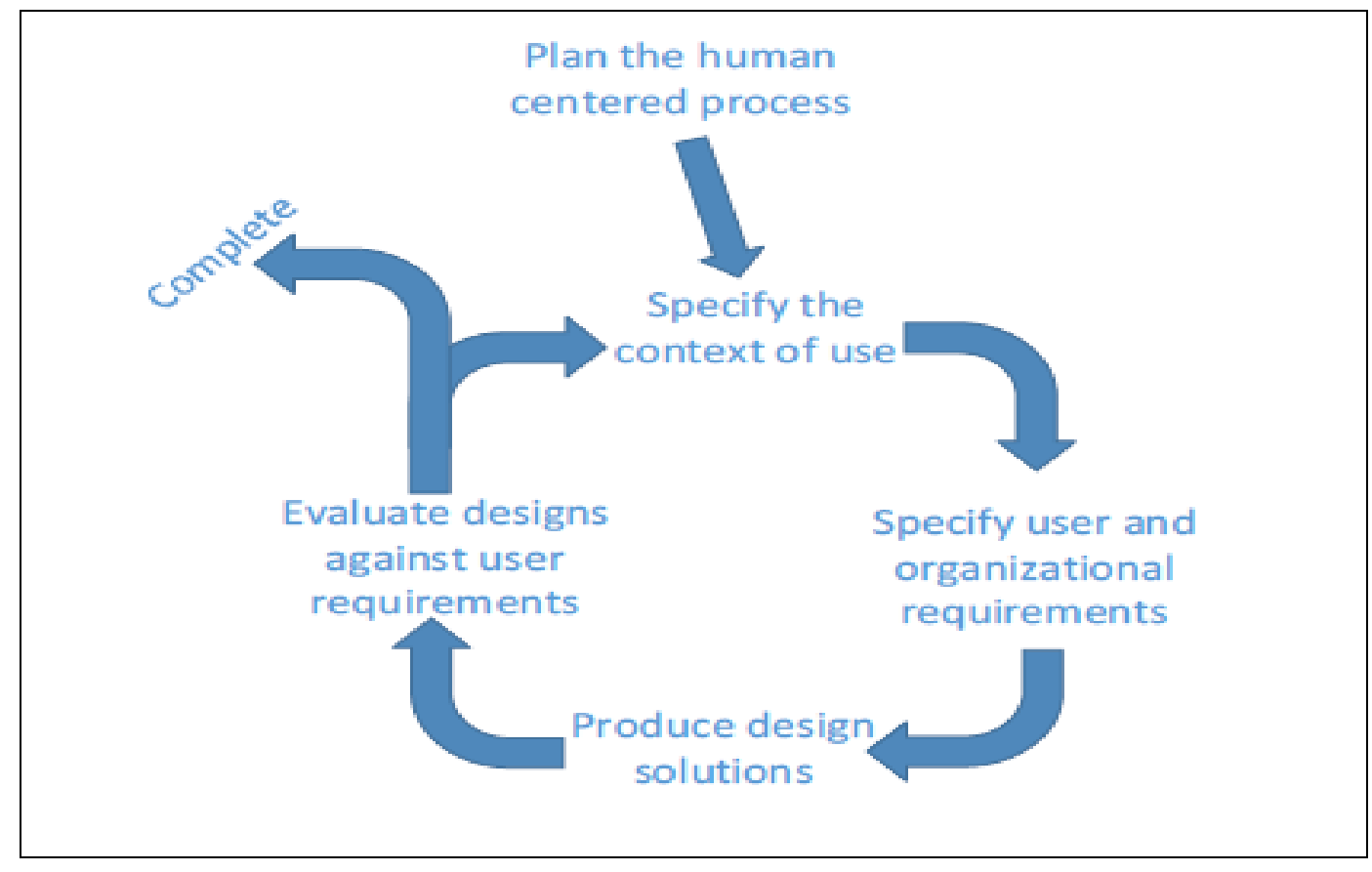

Gambar 3.2 Tahapan User Centered Design

Sumber : Intan Sandra Yatana Saputri tahun 2017

B. Prinsip-prinsip $U C D$

Adapun yang menjadi prinsip kerja dalam UCD (Ucer Centered Designr)

1. Fokus pada pengguna

2. Perancangan terintergrasi

3. Dari awal berlanjut pada penggujian pengguna

4. Perancangan interaktif. 


\subsubsection{Alat Bantu Analisis dan Perancangan Sistem}

\subsubsection{Perancangan}

Menurut Hutahean, dkk (2016:127), perancangan merupakan proses pemecahan masalah yang disertai dengan pemikiran yang kreatif guna mencapai hasil yang optimal. Kata perancangan atau dalam bahasa inggris desting mempunyai arti io plan and manage everything to be better, merencanakan atau mengatur segala sesuatu agar menjadi lebih baik.

\subsubsection{Flowchart}

Menurut Rosa dan Shalahuddin (2014:26), Flowchart ( Bagan Alir) adalah bagan (chart) yang menunjukkan alir (flow) di dalam program atau prosedur sistem secara logika. Bagan alir (flowchart) digunakan terutama untuk alat bantu komunikasi dan untuk dokumentasi. Bagan alir sistem digambar dengan menggunakan simbol-simbol yang tampak sebagai berikut ini.

Tabel 3.1 simbol Flowchart

\begin{tabular}{|c|c|c|c|}
\hline No & Gambar & Nama & Uraian \\
\hline 1 & $<$ & $\begin{array}{l}\text { Flow Direction } \\
\text { Symbol / } \\
\text { Connecting Line }\end{array}$ & $\begin{array}{l}\text { Berfungsi untuk menghubungkan simbol } \\
\text { yang satu dengan yang lainnya, } \\
\text { menyatakan arus suatu proses }\end{array}$ \\
\hline 2 & & $\begin{array}{l}\text { Communication } \\
\text { Link }\end{array}$ & $\begin{array}{l}\text { Untuk transmisi data dari satu lokasi ke } \\
\text { lokasi lain }\end{array}$ \\
\hline 3 & & Connector & $\begin{array}{l}\text { Digunakan untuk menyatakan sambungan } \\
\text { dari proses yang satu ke proses berikutnya } \\
\text { di halaman yang sama }\end{array}$ \\
\hline 4 & & $\begin{array}{l}\text { Offline } \\
\text { Connector }\end{array}$ & $\begin{array}{l}\text { Digunakan untuk menyatakan sambungan } \\
\text { dari proses yang satu ke proses berikutnya } \\
\text { di halaman yang sama }\end{array}$ \\
\hline 5 & & $\begin{array}{l}\text { Proses atau } \\
\text { langkah }\end{array}$ & $\begin{array}{l}\text { Menyatakan kegitan yang akan di } \\
\text { tampilkan dalam diagram alir. }\end{array}$ \\
\hline 6 & & $\begin{array}{l}\text { Manual } \\
\text { Operation }\end{array}$ & $\begin{array}{l}\text { Digunakan untuk menunjukkan pengoleh } \\
\text { yang tidak dilakukan oleh komputer }\end{array}$ \\
\hline & & Decision & $\begin{array}{l}\text { Proses atau langkah di mana perlu adanya } \\
\text { keputusan atau adanya kondisi tertentu. Di } \\
\text { titik ini selalu ada dua keluaran untuk }\end{array}$ \\
\hline
\end{tabular}




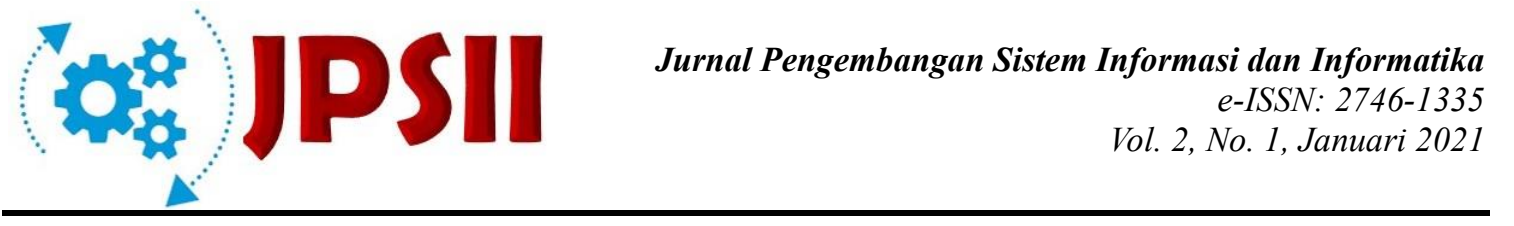

\begin{tabular}{|c|c|c|}
\hline 7 & & melanjutkan aliran kondisi yang berbeda \\
\hline 8 & $\begin{array}{l}\text { Predefined } \\
\text { Procces }\end{array}$ & $\begin{array}{l}\text { Digunakan untuk mempersiapkan } \\
\text { penyimpanan yang sedang / akan } \\
\text { digunakan dengan memberikan harga awal }\end{array}$ \\
\hline 9 & Terminal & $\begin{array}{l}\text { Digunakan untuk memulai atau } \\
\text { mengakhiri program }\end{array}$ \\
\hline 10 & Offline Storage & $\begin{array}{l}\text { Berfungsi untuk menunjukkan bahwa data } \\
\text { akan di simpan ke media tertentu }\end{array}$ \\
\hline 11 & $\begin{array}{l}\text { Manual Input } \\
\text { Symbol }\end{array}$ & $\begin{array}{l}\text { Digunakan untuk menginput data secara } \\
\text { manual dengan keyboard }\end{array}$ \\
\hline 12 & Input / Output & $\begin{array}{l}\text { Digunakan untuk menyatakan input dan } \\
\text { output tanpa melihat jenisnya. }\end{array}$ \\
\hline 13 & Punched Card & $\begin{array}{l}\text { Digunakan untuk menyatakan masukan } \\
\text { dan keluaran yang berasal dari card }\end{array}$ \\
\hline 14 & Disk Srtorage & $\begin{array}{l}\text { Digunakan untuk menyatakan masukan } \\
\text { dan keluaran yang berasal dari disk }\end{array}$ \\
\hline 15 & Magnetic Tape & $\begin{array}{l}\text { Digunakan untuk menyatakan masukan } \\
\text { dan keluaran yang berasal dari pita } \\
\text { magnetis }\end{array}$ \\
\hline 16 & Document & $\begin{array}{l}\text { Digunakan untuk menyatakan masukan } \\
\text { dan keluaran yang berasal dari dokumen }\end{array}$ \\
\hline 17 & Display & $\begin{array}{l}\text { Digunakan untuk menyatakan keluaran } \\
\text { melalui layar monitor }\end{array}$ \\
\hline
\end{tabular}




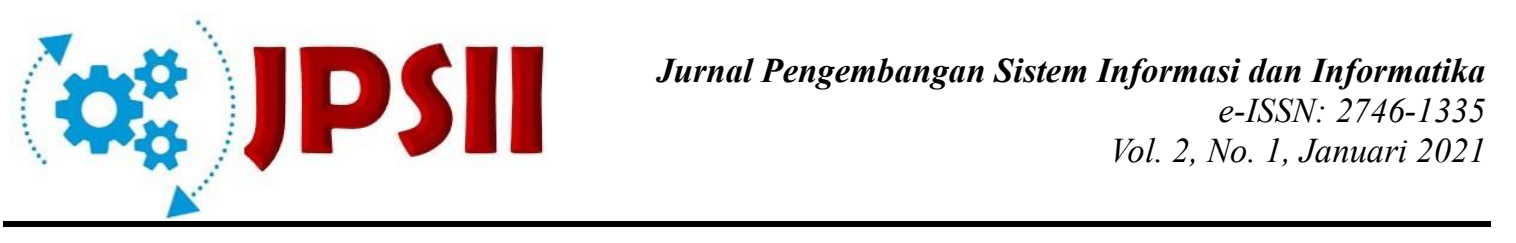

\section{Hasil dan Pembahasan}

\subsection{Analisa Masalah}

Dari hasil pengamatan dan penelitian yang di lakukan pada TK Angelly Kids Prabumulih, Guru memperkenalkan Alfabet kepada siswa/siswi dengan menulis terlebih dahulu di papan tulis lalu guru mengucapkan masing-masing huruf Alfabet tersebut dan di ikuti oleh siswa/siswi yang ada di sana. Metode pengajaran ini di rasa kurang efektif, anak merasa cepat bosan, beberapa siswa kurang mampu dalam menangkap yang di sampaikan oleh guru, serta guru kesulitan dalam mengambil alih perhatian murid saat belajar.

Berdasarkan analisa tersebut maka perlu adanya alternatif lain yang lebih efektif untuk mengenalkan dan mengajarkan mengenai alfabet, angka, buah, warna, hewan, bentuk dan kendaraan kepada anak usia dini melalui media interaktif atau game edukasi.

\subsection{Pemecahan Masalah}

Game Edukasi ini sangatlah penting untuk memudahkan siswa dan guru dalam proses belajar mengajar. Siswa tidak harus menggunakan buku panduan ketika belajar, namun bisa langsung melihat di depan layar komputer. Dengan game edukasi ini juga bisa membantu orang tua untuk mengajarkan anak nya di rumah mengenai Alfabet, Angka, Buah, Warna, Hewan, Benuk dan Kendaraan.

\subsection{Analisa Sistem Sedang Berjalan}

Tahap analisa ini penulis melakukan identifikasi masalah terhadap TK Angelly Kids Prabumulih, dari hasil penelitian tersebut diketahui permasalahan dalam proses belajar mengajar yang kurang efektif, anak merasa cepat bosan, beberapa siswa kurang mampu dalam menangkap apa yang di sampaikan oleh guru, serta guru kesulitan dalam mengambil alih perhatian murid saat belajar. Sistem yang di gunakan adalah Guru memperkenalkan Alfabet kepada siswa/siswi dengan menulis terlebih dahulu di papan tulis lalu guru mengucapkan masing-masing huruf Alfabet tersebut dan di ikuti oleh siswa/siswi yang ada di sana.

\subsection{Perancangan Sistem}

Perancangan antar muka merupakan penjelasan dari rancangan Game Edukasi, sehingga mendapatkan gamabaran Aplikasi Game Edukasi. Rancangan antar muka merupakan tampilan Aplikasi yang akan di buat sehingga dapat mempermudah dalam melakukan desain aplikasi. Adapun perancangan antarmuka meliputi perancangan Struktur menu dan rancangan input dan output yang akan membantu penjelasan lebih lanjut. 


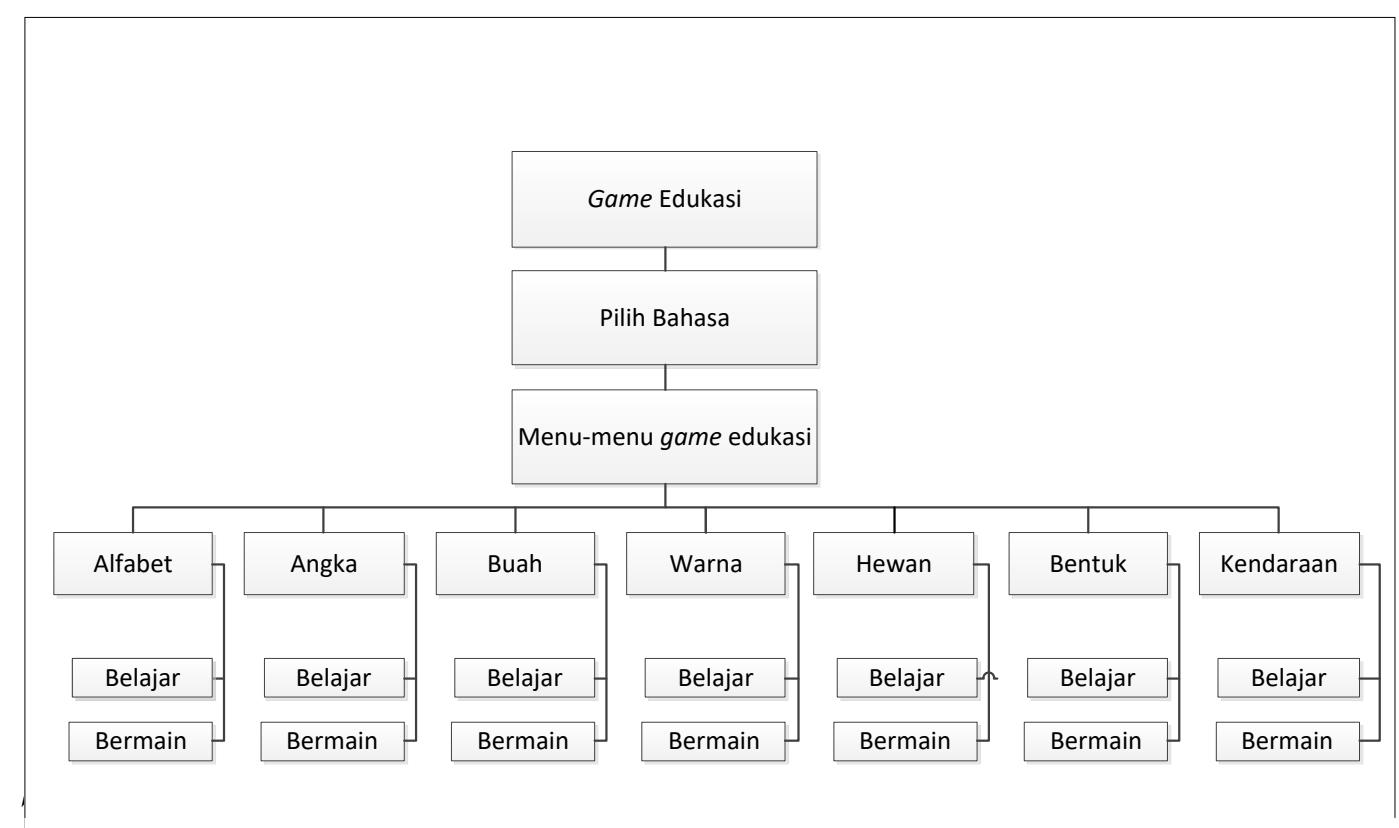

Gambar 4.1 Struktur Menu Utama

\title{
4.5 Flowchart
}

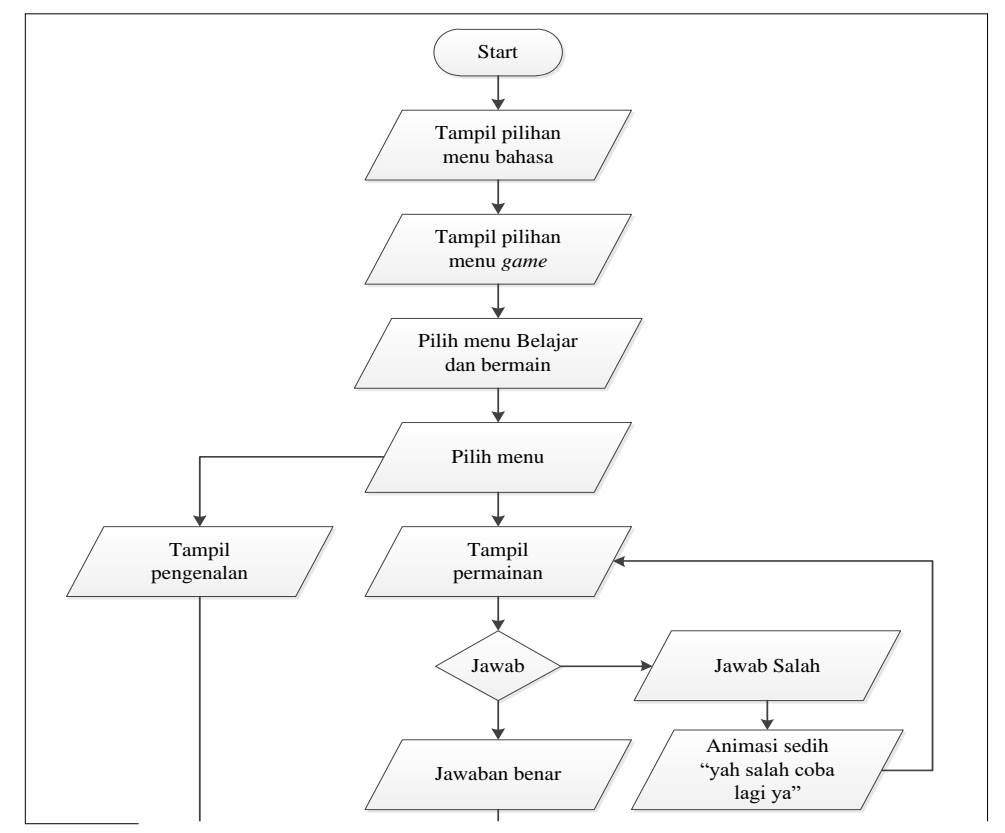

Gambar 4.2 Diagram Alir (Flowchart)

\begin{abstract}
$\downarrow$
Alur Flowcahrt ditunjukkan $\vec{p}_{2}$ End mbar 4.1 menggambarkan proses permainan game edukasi. Proses dimulai dari memperhatikan bahasa yang di pilih kemudian memilih menu yang terdapat dalam permainan game edukasi, setelah memilih menu tersebut game akan menampilkan pilihan belajar atau bermain, di saat kamu memilih menu belajar game
\end{abstract}


akan menampilkan pengenalan-pengenalan yang yang berhubungan dengan permainan, dan saat kamu memilih menu bermain maka game akan menampilkan pertanyaanpertanyaan yang berhubungan dengan menu belajar. Animasi sedih akan keluar jika jawaban mu salah, dan animasi tepuk tangan akan keluar jika jawaban mu benar.

\subsection{Perancangan Antar Muka}

a. Tampilan Halaman Beranda

Berikut adalah tampilan halaman beranda yang merupakan halaman utama dari sistem, dihalaman beranda terdapat beberapa menu yang dapat langsung di mainkan oleh pemain

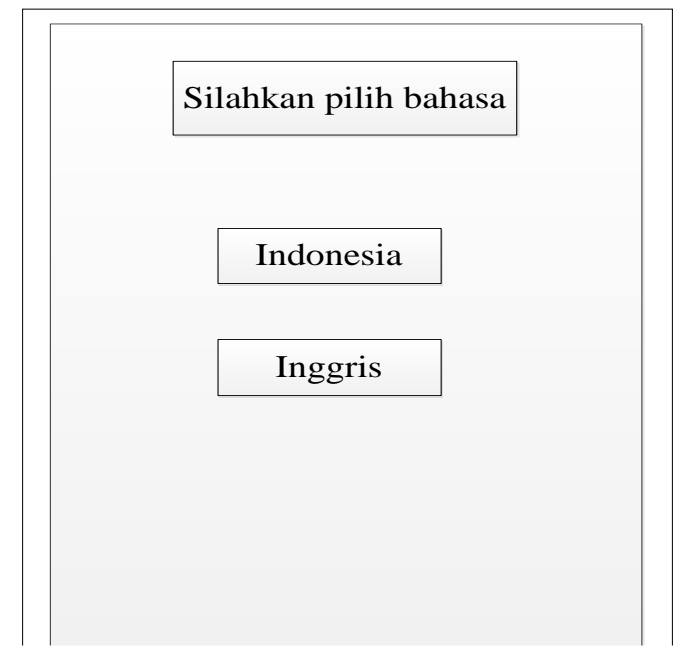

Gambar 4.3 Tampilan Halamaan beranda

b. Tampilan Halaman Menu Game Edukasi

Berikut adalah tampilan halaman Menu Game Edukasi

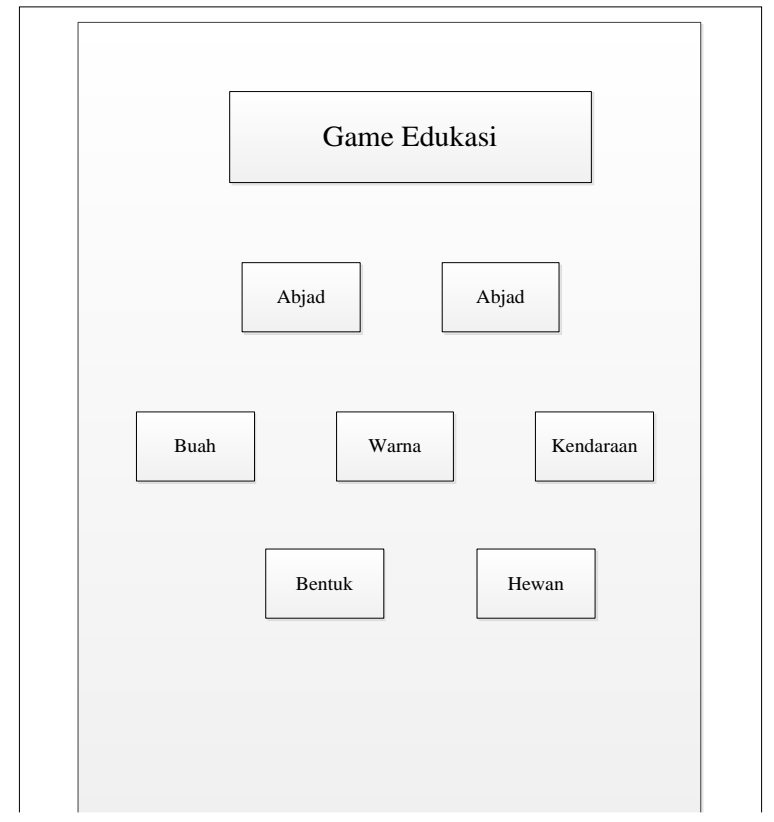

Gambar 4.4 Tampilan Halaman Menu Game Edukasi 
c. Tampilan Halaman Pilihan

Berikut adalah tampilan halaman setelah di klik menu Abjad.

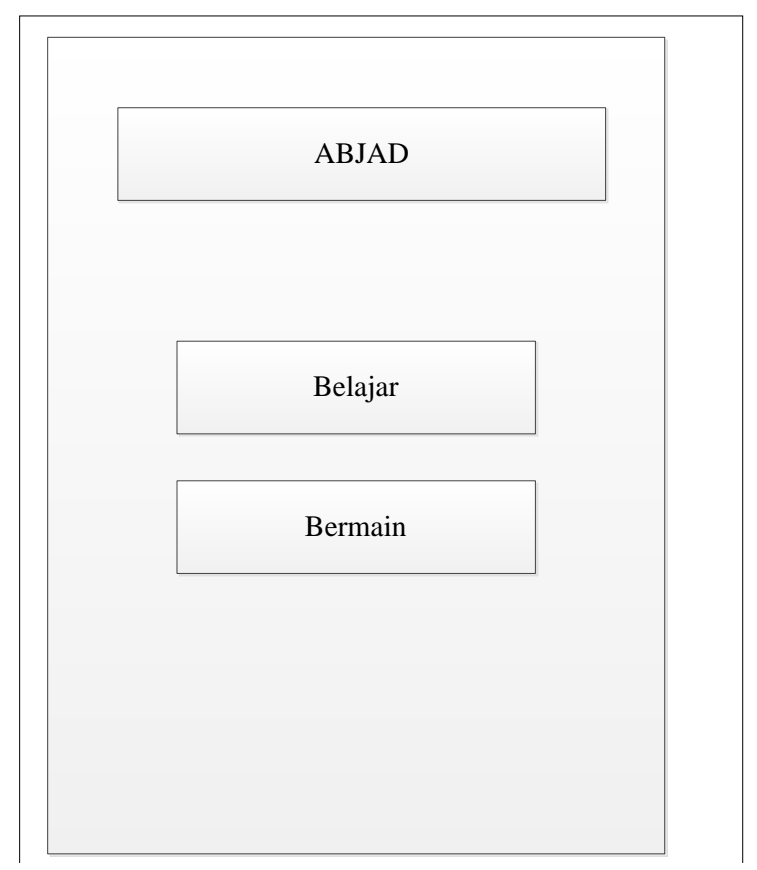

Gambar 4.5 Halaman Pilihan

d. Tampilan Halaman Belajar Abjad

Berikut adalah tampilan halaman setelah di klik menu belajar.

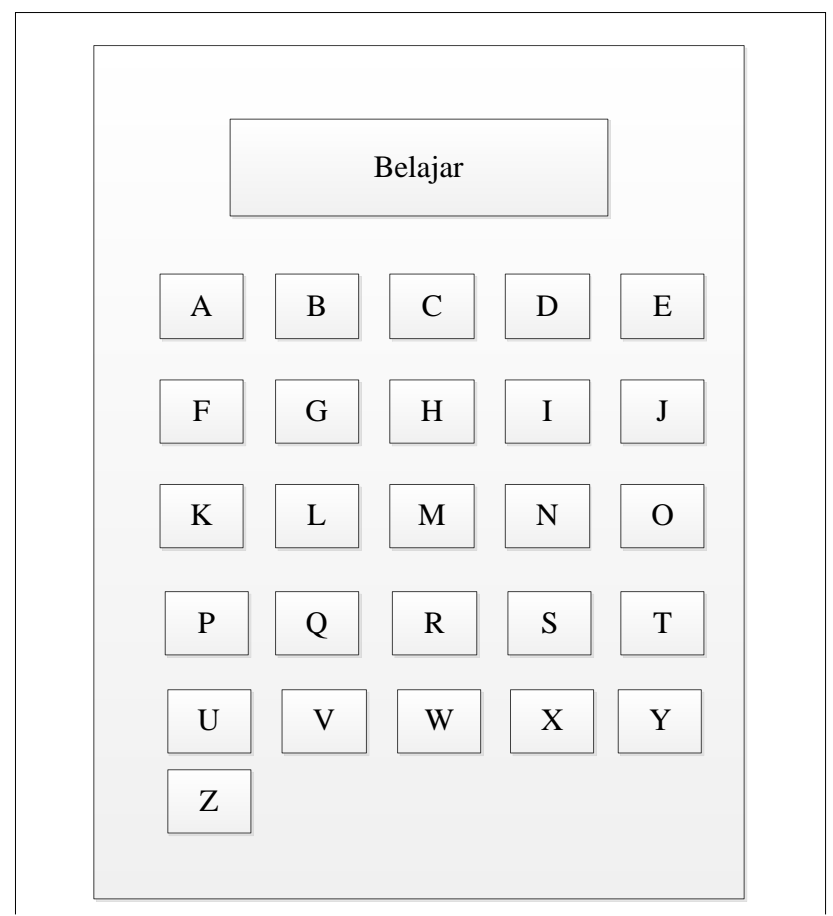

Gambar 4.6 Tampilan Halaman Belajar Abjad 
e. Tampilan Halaman Bermain

Berikut adalah tampilan halaman setelah di klik menu Bermain.

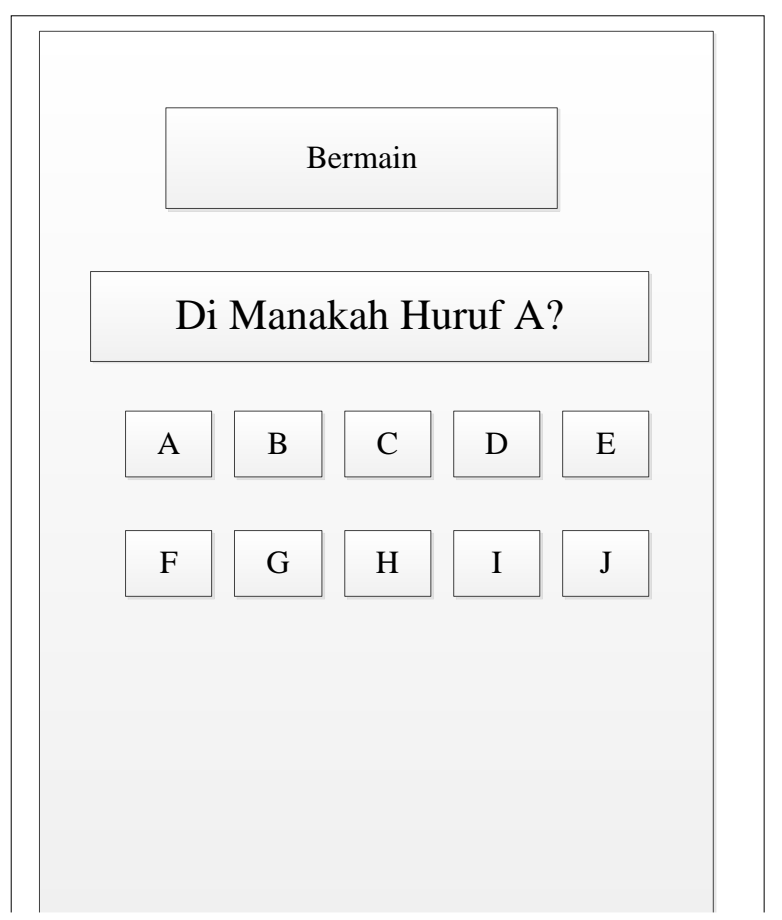

Gamabar 4.7 Tampilan Halaman Bermain

f. Halaman Jika Jawaban Benar

Berikut adalah tampilan halaman jika jawaban benar

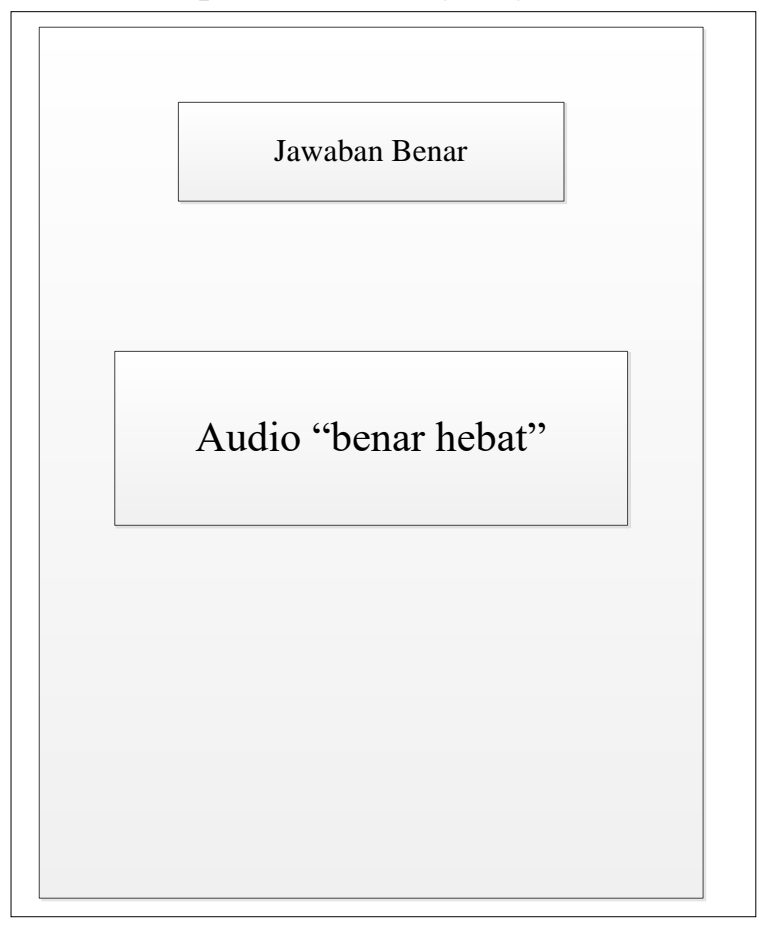




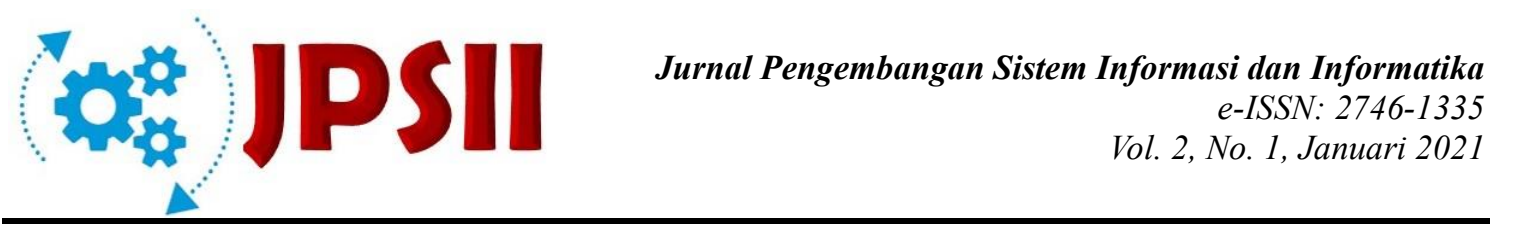

Gamabar 4.8 Tampilan Halaman jika jawaban benar

Berikut adalah tampilan halaman jika jawaban salah

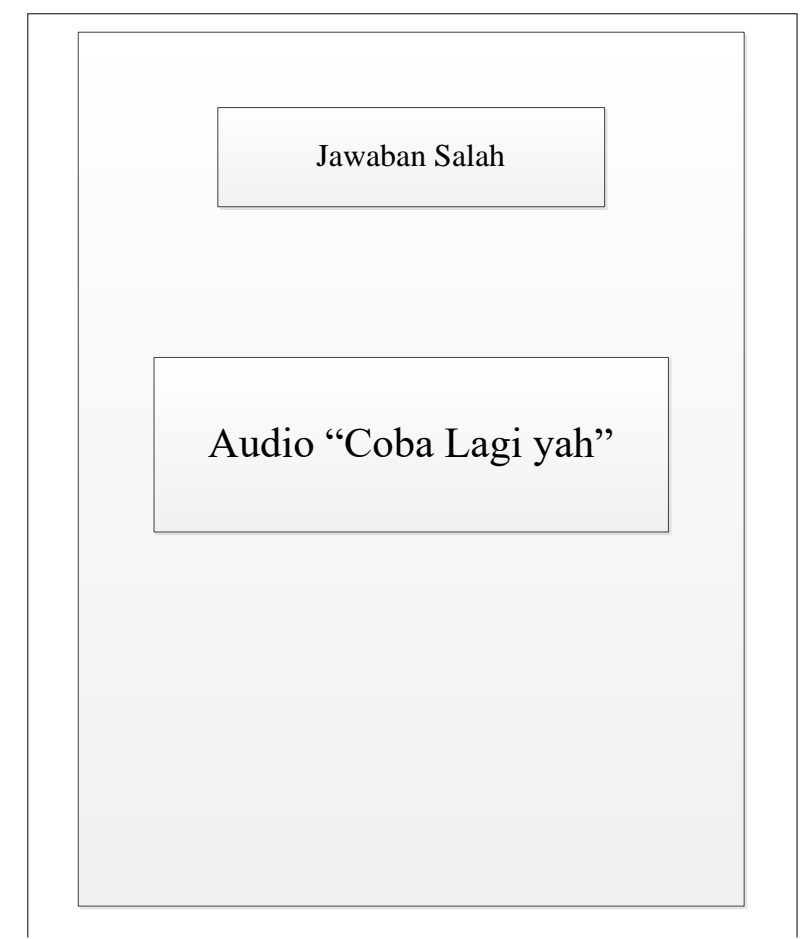

Gambar 4.9 Tampilan Halaman jika jawaban salah

\section{Kesimpulan}

Berdasarkan hasil perancangan dan pembangunan yang telah dijelaskan pada bab-bab sebelumnya tentang game edukasi anak usia dini berbasis android, dapat ditarik kesimpulan sebagai berikut:

a. Game edukasi dirancang dengan menggunakan bahasa pemrograman Adobe Flash CS.6.

b. Rancangan game ini terdiri dari bebarapa menu diantaranya: menu pilihan bahasa, menu game edukasi, menu pilihan dari menu belajar, dan menu bermain

c. Perancangan dan pembangunan aplikasi ini membantu anak usia 3-5 tahun untuk lebih memahami materi tentang pengenalan huruf, angka, buah, warna hewan, bentuk dan kendaraan. serta mengoptimalkan fungsi perangkat android yang dimiliki para orang tua untuk dijadikan sebagai alat edukasi bagi anak-anaknya.

d. Dengan dibangunnya aplikasi pembelajaran mobile berbasis android, ini menjadi salah satu media pembelajaran alternatif di antara pembelajaran yang lain seperti media pembelajaran menggunakan buku dan CD interaktif dalam meningkatkan dan mendukung proses pengenalan huruf, angka, buah, warna hewan bentuk dan kendaraan untuk anak usia 3-5 tahun.

\section{Referensi}

Antoni, D., Herdiansyah, M. I., Akbar, M., \& Sumitro, A. (2021). Pengembangan 
Infrastruktur Jaringan Untuk Meningkatkan Pelayanan Publik di Kota Palembang. JURNAL MEDIA INFORMATIKA BUDIDARMA, 5(4), 1652-1659.

Antoni, D., Jie, F., \& Abareshi, A. (2020). Critical factors in information technology capability for enhancing firm's environmental performance: case of Indonesian ICT sector. International Journal of Agile Systems and Management, 13(2), 159-181.

Antoni, D., \& Akbar, M. (2019). E-supply chain management value concept for the palm oil industry. Jurnal Sistem Informasi, 15(2), 15-29.

Antoni, D., Fikari, D., \& Akbar, M. (2018). The readiness of palm oil industry in enterprise resource planning. Telkomnika, 16(6), 2692-2702.

Fauzi, F., Dencik, A. B., \& Asiati, D. I. (2019). Metodologi Penelitian untuk manajemen dan akuntansi. Jakarta: Salemba Empat.

Abdillah, W. (2018). Metode Penelitian Terpadu Sistem Informasi Pemodelan Teoretis, Pengukuran dan Pengujian Statis. Yogyakarta: ANDI.

Ahmad Faris, A. F. (2016). Rancangan Animasi Interaktif Alfabet pada Pendidikan Anak Usia Dini . Jurnal Teknik Komputer, Vol. II No.1 ISSN : 2442-2436.

Akip Suhendra, Z. M. (2014). Media Pembelajaran Mengenal Bentuk dan Warna Berbasis Multimedia pada RA AL-A'RAF. Jurnal Teknologi Informasi, Vol.I ISSN : 2406-7741.

Dana Pranata, H. D. (2015). Rancang Bangun Website Jurnal Ilmiah Bidang Komputer . Jurnal Informatika Mulawarman, Vol.1 No.2 .

Eliza. (2012). Program Terhebat Android. Jakarta: Gramedia.

Emanuel, A. W. (2017). Metode Penelitian Teknologi Informasi. Yogyakarta: ANDI.

I Dewa Putu Agus Sudiatmika, A. K. (2014). Aplikasi Game Edukasi Trash Grabber untuk Mengenal Jenis-Jenis Sampah pada Smartphone Berbasis Android. Jurnal Teknologi Informasi, Vol. 2 No.2 ISSN : 2252-3006.

Muhammad Iqbal Hanafri, A. B. (2015). Game Edukasi Tebak Gambar Bahasa Jawa menggunakan Adobe Flash CS6 berbasis Android. Jurnal SISFOTEK Global, Vol.5 No.2 ISSN :2088-1762.

Putri Ludviyah Ekawati, A. Z. (2015). Pemnafaatan Teknologi Game untuk Pembelajaran Mengenal Ragam Budaya Indonesia berbasis Android. Jurnal Sistem Komputer, Vol. 22 No.1 ISSN : 1858-4667.

Rosa A.S, M. S. (2014). Rekayasa Perangkat Lunak Terstruktur dan Berorientasi Objek. Bandung :

Sugiyono. (2015). Metode Penelitian Kuantitatif, Kualitatif dan R\&D. Bandung: Alfabeta.

Sujiono, Y. N. (2013). Konsep Dasar Pendidikan Anaka Usia Dini. Jakarta: INDEKS.

Supriadi, Y. (2017). Semua Bisa Menjadi Programer Android Case Study. Jakarta: Gramedia.

\section{Copyrights}


Copyright for this article is retained by the author(s), with first publication rights granted to the journal.

This is an open-access article distributed under the terms and conditions of the Creative Commons Attribution license (http://creativecommons.org/licenses/by/4.0/) 